\title{
Hidrotic ectodermal dysplasia, Christianson-Fourie type
}

INSERM

\section{Source}

INSERM. (1999). Orphanet: an online rare disease and orphan drug data base. Hidrotic ectodermal dysplasia, Christianson-Fourie type. ORPHA:1808

Hidrotic ectodermal dysplasia, Christianson-Fourie type is a rare ectodermal dysplasia syndrome characterized by tricho- and onychodysplasia in association with cardiac rhythm abnormalities. Patients present with sparse scalp hair and eyelashes, absent or sparse eyebrows, dystrophic thickened nails (on fingers distal end may be lifted from the nail bed) and supraventricular tachicardia or sinus bradicardia. 